\title{
Practical Use of Amino Acids in Oncology: Replacement Therapy as a Structural Components of Proteins and/or for Correction of Metabolism in Quantities Comparative with their Endogenous Concentrations?
}

\author{
L Nefyodov ${ }^{1 *}$ and N Karavay ${ }^{2}$ \\ ${ }^{1}$ Department of Biochemistry, Yanka Kupala Grodno State University, Belarus \\ ${ }^{2}$ Department of Hyperbaric oxygenation, Grodno Regional Clinical Hospital, Belarus
}

*Corresponding author: L Nefyodov, Department of Biochemistry, Yanka Kupala Grodno

State University, Belarus.

Received Date: April 23, 2019

Published Date: May 08, 2019

\section{Introduction}

The aim of our research is the formulation of methodology creation for practical application of the regulatory action of endogenous (physiological) concentrations of separate amino acids or their pathogenetically justified compositions [1-4]. Changes in amino acid pool in liquids and their tissues fund of oncology patients specifically characterize development of cancer and largely induced by metabolic competition between the tumor and the tumor carrier [5-10]. Correction of the intermediate metabolic changes in cancer can be reached by the use of certain amino acids or their combinations. Based on the positions of metabolomics, the free amino acid pool in biological fluids and tissues is regarded as a single information unit which is a kind of "a chemical projection" of the genome, the proteome realized through this approach not only develops ideas about the pool of amino acids as a dynamical system-generated supply of them from outside, but also due to endogenous synthesis, transport, degradation and excretion and allows the identification of "key points" in intermediate metabolic equilibrium shift that may reflect ratios at the individual levels of endogenous amino acids and related species (metabolicallyrelated) compounds to achieve "metabolic comfort" [11-15].

On the basis of the experimental data we suggest that the differences discovered in certain amino acids concentrations in fluids and tissues are criteria in early diagnostics as in estimation of the efficacy of specific cancer treatment. Our clinical studies on biological fluids and tumors more than 1400 patients with cancer depending on the location and stage of the process showed significant changes in physiological concentrations of amino acids which either directly or indirectly regulate processes of antitumor response, oncogenesis, immunogenesis and apoptosis were shown [16-18]. The creation methodology of pathogenetic compositions of amino acids and their derivatives on the basis of their physiological concentration for practical application of their regulatory effects in oncology was discussed.

\section{Acknowledgement}

None.

\section{Conflict of Interest}

No conflict of interest.

\section{References}

1. Nefyodov L (1999) Taurine (biochemistry, pharmacology, medical application) Grodno RIPH, P.145.

2. L Nefyodov (1996) Amino Acids and Their Derivatives (chemistry, biochemistry, pharmacology, medicine). Proc of Internat. Symp; Grodno. P.125.

3. Nefyodov LI, Karavay PA, Karavay NL (2014) Regulatory action of free amino acids and development on the basis of highly of substances infusion solutions with pathogenetic deterministic composition. Laboratory diagnosis Eastern Europe 3: 111-115.

4. Nefyodov LI (2010) The results of biochemical research and development of nitrogen-containing compounds of natural origin: methodology of exploitation of biological properties as universal natural regulators of metabolism and drugs.

5. Nefyodov LI, Uglyanica KN, Smirnov VY, Doroshenko YM, Fomin KA, et al. (1996) Amino acids and their derivatives in tumor tissue from patients 
with breast cancer treated with Ukrain. Part VI. Drugs Exp Clin Res 22(35): 155-157.

6. Nefyodov LI, Uglyanica KN, Smirnov VY, Doroshenko YM, Fomin KA, et al. (1996) Amino acids and their derivatives in blood plasma of patients with breast cancer treated with Ukrain. Part V. Drugs Exp Clin Res 22(35): 159-161.

7. Nefyodov LI (1999) Biological activity and transport of drugs. Proc of Internat. Symp; Grodno p.189.

8. Nefyodov LI (2000) VI Ordinary General Assembly Society of Biochemistry of Belarus. Proc of Internat. Symp; Grodno p.225.

9. Nefyodov LI (2001) Amino acids and their derivatives in biology and medicine. Proc of Internat. Symp; Grodno p.124.

10. Nefyodov LI (2001) Target - oriented regulation of metabolic equilibrium by amino acids and strategy of their application as drugs with directional effects. XXXVII Zjazd Polskiego towarzystwa biochemicznego, Torun p.327.

11. Ihata Y, Miyagi E, Numazaki R (2013) Amino acid profile index for early detection of endometrial cancer: verification as a novel diagnostic marker. Int J Clin Oncol 19(3): 364-372.

12. Fafournoux P, Bruhat A, Jousse C (2000) Amino acid regulation of gene expression. BioChem J 351(1): 1-12.
13. Meijer A (2003) Amino acids as regulators and components of nonproteinogenic pathways. J Nutr 6(1): 2057S-2062S.

14. Bruhat A, Cherasse Y, Chaveroux C, Maurin AC, Jousse C, et al. (2009) Amino acids as regulators of gene expression in mammals: molecular mechanisms. Biofactors 35(3):249-257.

15. Ananieva E (2015) Targeting amino acid metabolism in cancer growth and anti-tumor immune response. World J Biol Chem 6(4): 281-289.

16. Karavay PA (2016) Amino acids in Metabolomics: Perspective for the Use of Regulatory effects of Fee Amino Acids in the Creation on their Basis of Infusion Solutions. In: Karavay P, Nefyodov LI, Karavay NL, International Journal of Hematology \& Therapy, 2(2): 1-2.

17. Karavay A (2016) Metabolic Comfort in Oncology and Free Amino Acids: Perspectives for the Use of Their Regulatory Actions in Physiological Concentrations. In: Karavay A, Karavay P, Koliada T, Nefyodov L, Academic Web Journal of Medical Science 1 (1): 001-004.

18. Takashi Anayama (2018) Post-operative AICS status in completely resected lung cancer patients with pre-operative AICS abnormalities: predictive significance of disease recurrence. Scientific Reports 8: 12378. 